\title{
Cerium(III)-Catalyzed Addition of Diethylzinc to Carbonyl Compounds ${ }^{1}$
}

\author{
Stefan Fischer, ${ }^{\mathrm{a}}$ Ulrich Groth, ${ }^{* a}$ Mario Jeske, ${ }^{\mathrm{b}}$ Thorben Schütz ${ }^{\mathrm{a}}$ \\ a Fachbereich Chemie, Universität Konstanz, Fach M-720, Universitätsstr. 10, 78457 Konstanz, Germany \\ E-mail: Ulrich.Groth@uni-konstanz.de \\ b Bayer AG, PH-R-EU-CR, 42096 Wuppertal
}

\begin{abstract}
CeCl}_{3}$ catalyzes the addition of $\mathrm{Et}_{2} \mathrm{Zn}$ to a variety of alipahtic and aromatic aldehydes and ketones in THF in the presence of $\mathrm{TMSCl}$ as a scavenger. Optimization of the applied solvent allowed to avoid the TMSCl mediated addition using $\mathrm{CeCl}_{3} \cdot(\mathrm{THF})_{2}$ or $\mathrm{Ce}(i-\mathrm{PrO})_{3}$ as catalysts. This represents the first application of lanthanide compounds for the addition of $\mathrm{Et}_{2} \mathrm{Zn}$ to carbonyl compounds.
\end{abstract}

Key words: lanthanides, cerium, catalysis, diethylzinc, addition to carbonyls

Over the last decades lanthanides due to their high oxophilicity have provoked increasing interest in organic chemistry. Numerous examples for their versatile utility are known. ${ }^{2}$ Catalytic processes, however, which take advantage of the unique properties of lanthanides are still rare. Recently, we have reported that cerium(III)-alkoxides catalyze the reductive coupling of carbonyl compounds to the corresponding pinacols highly diastereoselectively and in excellent yields. ${ }^{3}$

The addition of diethylzinc to aldehydes is currently under investigation by a number of research groups, which have already reached significant success regarding chemical yields and enantiomeric purities of the addition products. The use of catalytic amounts of enantiomerically pure aminoalcohols as Lewis bases as well as the use of chiral transition metal complexes as Lewis acids, e.g. titanium, are commonly described. ${ }^{4-6}$ Herein, we wish to report the first example of a cerium(III)-catalyzed addition of diethylzinc to carbonyl compounds. To the best of our knowledge this reaction has not yet been described with other lanthanide compounds.

We have observed that the addition proceeds in excellent yields with the use of trimethylsilylchloride as a scavenger in THF and with anhydrous cerium(III)-chloride as catalyst. Optimization of the catalyst amounts was investigated first. Applying cerium(III)-chloride in stoichiometric quantities the addition product of diethylzinc to benzaldehyde was isolated almost quantitatively. Decreasing the amount of cerium(III)-chloride allowed the reaction to proceed in excellent yields. Optimal reaction conditions were determined by using $5 \mathrm{~mol} \% \mathrm{CeCl}_{3}, 1.5$ equivalents $\mathrm{TMSCl}$ and 2.0 equivalents diethylzinc.
As a second reaction parameter the influence of the reaction temperature on the yield was optimized. The results of the cerium-catalyzed addition of diethylzinc to benzaldehyde are shown in Table 1 . Variation of the reaction temperature in a range from $-78{ }^{\circ} \mathrm{C}$ to $-50{ }^{\circ} \mathrm{C}$ led to low yields of phenyl-1-propanol only (Table 1, entries 1 and 2 ). By increasing the reaction temperature higher yields of the addition product were observed (Table 1, entries 3 and $4)$. The optimal reaction temperature was room temperature (93\% yield, Table 1, entry 5). Higher reaction temperatures resulted in lower yields probably caused by decomposition of diethylzinc (Table 1, entry 6).

Table 1 Influence of the Reaction Temperature of the $\mathrm{CeCl}_{3}$ Catalyzed Addition of Diethylzinc to Benzaldehyde

\begin{tabular}{|c|c|c|}
\hline $\begin{array}{l}\mathrm{Ph}^{\prime} \\
\quad\end{array}$ & $\begin{array}{l}\text { 1) } 5 \mathrm{~mol} \% \mathrm{CeCl}_{3} \\
1.5 \mathrm{eq} \mathrm{TMSCl} \\
2.0 \text { eq } \mathrm{Et}_{2} \mathrm{Zn}, \mathrm{THF} \\
\stackrel{2) \text { sat. aq. } \mathrm{NH}_{4} \mathrm{Cl}}{\longrightarrow}\end{array}$ & \\
\hline Entry & Temp $\left({ }^{\circ} \mathrm{C}\right)$ & Yield $(\%)^{\mathrm{a}}$ \\
\hline 1 & -78 & 11 \\
\hline 2 & -50 & 23 \\
\hline 3 & -35 & 70 \\
\hline 4 & 0 & 88 \\
\hline 5 & 25 & 93 \\
\hline 6 & 50 & 90 \\
\hline
\end{tabular}

${ }^{\mathrm{a}}$ Yields refer to isolated products.

Scope and limitations of the presented cerium catalyzed addition reaction were investigated next. Different carbonyl compounds were converted to their addition products under the optimized reaction conditions described above. The reaction of aromatic and aliphatic aldehydes led to excellent yields and the corresponding secondary alcohols were isolated in more than $90 \%$ yield (Table 2, entries $1-3)$. Acetophenone was converted in $87 \%$ yield to 1methyl-1-phenyl-propion-1-ol (Table 2, entry 4).

To discuss the regioselectivity of the reaction, the ceriumcatalyzed addition of diethylzinc to benzylidenacetone was investigated. It proceeded in a highly 1,2-selective manner with a yield of $73 \%$ (Table 2, entry 5). The 1,4product was not isolated. The lower reactivity of ketones in comparison to aldehydes resulted in decreasing yields 
Table $2 \mathrm{CeCl}_{3}$-Catalyzed Addition of Diethylzinc to Different Carbonyl Compounds

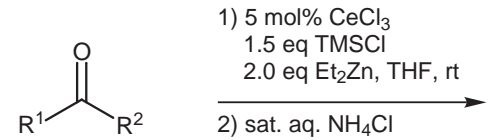

3

\begin{tabular}{lllll}
\hline Entry & $\mathrm{R}^{1}$ & $\mathrm{R}^{2}$ & Time $[\mathrm{h}]$ & ${\text { Yield }[\%]^{\mathrm{a}}}^{-}$ \\
\hline 1 & $\mathrm{Ph}$ & $\mathrm{H}$ & 15 & 93 \\
2 & $p-\mathrm{MeOPh}$ & $\mathrm{H}$ & 15 & 95 \\
3 & $c-\mathrm{C}_{6} \mathrm{H}_{11}$ & $\mathrm{H}$ & 15 & 90 \\
4 & $\mathrm{Ph}$ & $\mathrm{Me}$ & 48 & 87 \\
5 & $\mathrm{Ph}(\mathrm{CH}=\mathrm{CH})$ & $\mathrm{Me}$ & 72 & 73 \\
\hline
\end{tabular}

${ }^{\mathrm{a}}$ Yields refer to isolated products.

(Table 2, entries 4 and 5 vs 1-3). Even when the reaction time was prolonged, starting material was still present.

A disadvantage of TMSCl as a scavenger is its ability to mediate the addition of diethylzinc to aldehydes, even without a catalyst, up to $20 \%$ at room temperature. ${ }^{7}$ The fact that the reactivity of diethylzinc increases as the polarity of the solvent decreases enabled us to show that, presumably due to enhanced transmetalation, the $\mathrm{CeCl}_{3} \cdot(\mathrm{THF})_{2}$ complex alone is sufficient to catalyze the addition reaction when toluene is used as solvent (Table 3 , entries 1 and 2). Due to side reactions longer reaction times do not improve yields significantly. Low solubility of $\mathrm{CeCl}_{3} \cdot(\mathrm{THF})_{2}$ in toluene causes lower concentration of active catalyst which prohibits higher yields. To improve solubility, mixtures of toluene and THF were investigated and optimal yields were obtained using a 5:1 ratio (Table 3, entry 3).

Table 3 Ce(III)-Catalyzed Addition of Diethylzinc to Benzaldehyde
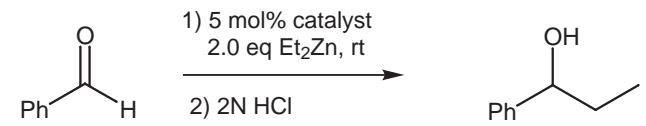

1

5

\begin{tabular}{lllll}
\hline Entry & Solvent & Catalyst & Time (h) & Yield $(\%)^{\mathrm{a}}$ \\
\hline 1 & Toluene & - & 18 & $<5$ \\
2 & Toluene & $\mathrm{CeCl}_{3} \cdot(\mathrm{THF})_{2}$ & 18 & 35 \\
3 & $5: 1^{\mathrm{b}}$ & $\mathrm{CeCl}_{3} \cdot(\mathrm{THF})_{2}$ & 18 & 52 \\
4 & $3: 1^{\mathrm{b}}$ & $\mathrm{CeCl}_{3} \cdot(\mathrm{THF})_{2}$ & 18 & 25 \\
5 & $1: 1^{\mathrm{b}}$ & $\mathrm{CeCl}_{3} \cdot(\mathrm{THF})_{2}$ & 18 & 7 \\
6 & Toluene & $\mathrm{Ce}(i-\mathrm{PrO})_{3}$ & 18 & 48 \\
7 & Toluene & $\mathrm{Ce}(i-\mathrm{PrO})_{3}$ & 34 & 58
\end{tabular}

a Yields refer to isolated products.

b Toluene:THF ratio.
Cerium(III)-isopropoxide ${ }^{8}$ is readily soluble in toluene and therefore it is possible to avoid complex solvent mixtures. Optimized reaction conditions require the use of only $5 \mathrm{~mol} \% \mathrm{Ce}(i-\mathrm{PrO})_{3}$ and 2 equivalents of diethylzinc (Table 3, entry 6). An extended reaction time increased the yield significantly (Table 3 , entry 7 ), whereas prolonged reaction times of more than 34 hours led to side reactions such as the Meerwein-Ponndorf-Verley reduction, but no pinacol coupling was observed. Even after these long reaction times starting material was still remaining in all cases.

Table 4 shows a few examples of the $\mathrm{Ce}(\mathrm{O}-i-\mathrm{Pr})_{3}$ system. ${ }^{9}$ They illustrate that electron withdrawing nitrile substituents in para- and meta-position led to improved yields of addition product. ortho-Substitution causes a decrease in yield presumably due to steric effects.

Table $4 \mathrm{Ce}(i \text {-PrO })_{3}$-Catalyzed Addition of Dietylzinc to Various Substituted Benzaldehydes

\begin{tabular}{|c|c|c|}
\hline 6 & $\begin{array}{l}\text { 1) } 5 \mathrm{~mol} \% \mathrm{Ce}(\mathrm{O}-i-\mathrm{Pr})_{3} \\
2.0 \text { eq } \mathrm{Et}_{2} \mathrm{Zn} \text {, toluene, rt, 34h } \\
\text { 2) } 2 \mathrm{~N} \mathrm{HCl}\end{array}$ & $\stackrel{\mathrm{OH}}{l}$ \\
\hline Entry & $\mathrm{R}$ & Yield $[\%]^{\mathrm{a}}$ \\
\hline 1 & $p$-NC-Ph & 67 \\
\hline 2 & $m$-NC-Ph & 59 \\
\hline 3 & $o-\mathrm{NC}-\mathrm{Ph}$ & 22 \\
\hline 4 & $p$-MeO-Ph & $10^{\mathrm{b}}$ \\
\hline
\end{tabular}

a Yields refer to isolated products.

b $50{ }^{\circ} \mathrm{C}$.

The electron donating methoxy substituent prevented any addition reaction at room temperature and required harsher reaction conditions (Table 4, entry 4).

In summary, we developed a novel cerium-catalyzed addition of zincorganyls to carbonyl compounds. We were able to reach high yields using TMSCl as a scavenger and cerium(III)-chloride as catalyst in THF. Using $\mathrm{CeCl}_{3} \cdot(\mathrm{THF})_{2}$ and $\mathrm{Ce}(i \text {-PrO })_{3}$ in toluene, respectively, it is possible to avoid the TMSCl mediated addition. Future efforts will be directed towards variation of ligands for the applied cerium catalyst in order to improve the chemical yields as well as to run this process in an asymmetric fashion.

\section{Acknowledgement}

The authors are grateful to the Fonds der Chemischen Industrie and the EU-Commission, Directorate XII, for financial support. M. J. thanks the Stiftung Stipendienfonds des Verbandes der Chemischen Industrie, S. F. the Cusanuswerk - Bischöfliche Hochbegabtenförderung and T. S. the Konrad-Adenauer-Stiftung for a Ph.D. fellowship. We also thank Witco for the generous donation of diethylzinc. 


\section{References}

(1) Lanthanides in Organic Synthesis, part 5. For part 4, see ref. $3 b$.

(2) (a) Molander, G. A. Chem. Rev. 1992, 92, 29. (b) Imamoto, T. Lanthanides in Organic Synthesis; Academic Press: London, 1999. (c) Kobayashi, S. Lanthanides: Chemistry and Use in Organic Synthesis; Springer Verlag: Heidelberg, 1999.

(3) (a) Groth, U.; Jeske, M. Angew. Chem. Int. Ed. 2000, 39, 574. (b) Groth, U.; Jeske, M. Synlett 2001, 129.

(4) For a review, see: (a) Soai, K.; Niwa, S. Chem. Rev. 1992, 92, 833. (b) Soai, K.; Shibata, T. In Comprehensive Asymmetric Catalysis; Jacobsen, E. N., Ed.; Springer Verlag: Heidelberg, 2000, chap. 26.1.

(5) Lewis bases: (a) Langer, F.; Schwinjk, L.; Devasagayaraj, A.; Chavant, P.-V.; Knochel, P. J. Org. Chem. 1996, 61, 8229. (b) Kitamura, M.; Oka, H.; Noyori, R. Tetrahedron 1999, 55, 3605. (c) Soai, K.; Yokoyama, S.; Ebihara, K. J. Chem. Soc., Chem. Commun. 1987, 1690. (d) Rosini, C.; Franzini, L.; Pini, D.; Salvadori, P. Tetrahedron: Asymmetry 1990, 1, 587. (e) Kitajima, H.; Ito, K.; Aoki, Y.; Katsuki, T. Bull. Chem. Soc. Jpn. 1997, 70, 207. (f) Huang, W.; Hu, Q.; Pu, L. J. Org. Chem. 1998, 63, 1364. (g) Cobb, A. J. A.; Marson, C. M. Tetrahedron: Asymmetry 2001, 12, 1547. (h) Nevalainen, M.; Nevalainen, V. Tetrahedron: Asymmetry 2001, 12, 1771. (i) Liu, D.-X.; Zhang, L.-C.; Wang, Q.; Da, C.-S.; Xin, Z.-Q.; Wang, R.; Choi, M. C. K.; Chan, A. S. C. Org. Lett. 2001, 3, 2733. (j) Schinnerl, M.; Seitz, M.; Kaiser, A.; Reiser, O. Org. Lett. 2001, 3, 4259.
(6) Lewis acids: (a) Yoshioka, M.; Kawakita, T.; Ohno, M. Tetrahedron Lett. 1989, 30, 1657. (b) Seebach, D.; Plattner, D. A.; Beck, A. K.; Wang, Y. M.; Hunziker, D. Helv. Chim. Acta 1992, 75, 2171. (c) Keller, F.; Rippert, A. J. Helv. Chim. Acta 1999, 82, 125. (d) Nakamura, Y.; Takeuchi, S.; Ohgo, Y.; Curran, D. P. Tetrahedron Lett. 2000, 41, 57. (e) Fan, Q.-H.; Liu, G.-H.; Chen, X.-M.; Deng, G.-J.; Chan, A. S. C. Tetrahedron: Asymmetry 2001, 12, 1559.

(7) (a) Corey, E. J.; Boaz, N. W. Tetrahedron Lett. 1985, 26, 6019. (b) Matszawa, S.; Horiguchi, Y.; Nakamura, E.; Kuwajima, I. Tetrahedron 1989, 45, 349. (c) Jeske, M. Ph.D. Dissertation; Universität: Konstanz, 2000.

(8) (a) Mehrotra, R. C.; Batwara, J. M. Inorg. Chem. 1970, 9, 2505. (b) Groth, U.; Eckenberg, P.; Köhler, T. Liebigs Ann. Chem. 1994, 673.

(9) General Experimental Procedure: The reactions were carried out under argon atmosphere using Schlenk techniques. Substances, which are sensitive against moisture and oxidation were stored in a glove box. Reactions were typically performed on a $1.5 \mathrm{mmol}$ scale. In a Schlenk tube $5 \mathrm{~mL}$ of solvent were added to the catalyst (usually $0.075 \mathrm{mmol}, 0.05$ equiv). Then, $3 \mathrm{~mL}$ of an $1 \mathrm{M}$ solution of diethylzinc ( $3 \mathrm{mmol}, 2$ equiv) in the applied solvent were transferred to the reaction via canulla. To the reaction mixture $1.5 \mathrm{~mL}$ of a $1 \mathrm{M}$ solution of aldehyde $(1.5 \mathrm{mmol}$, 1 equiv) in the used solvent were then added slowly by using a syringe pump. When TMSCl was used as a scavenger $1.5 \mathrm{~mL}$ of a $1.5 \mathrm{M}$ solution ( $2.25 \mathrm{mmol}, 1.5$ equiv) in the chosen solvent were added simultaneously using the same syringe pump. After careful addition of $25 \mathrm{~mL}$ of sat. aq $\mathrm{NH}_{4} \mathrm{Cl}$ or $2 \mathrm{~N} \mathrm{HCl}$, respectively, the aqueous phase was extracted with ethylether $(3 \times 30 \mathrm{~mL})$. The combined and dried $\left(\mathrm{MgSO}_{4}\right)$ organic layers were then liberated from the solvent and purified by flash chromatography eluting with EtOAc/petroleum ether. 